\title{
Book Review: Karen An-Hwei Lee (2013). Anglophone Literatures In The Asian Diaspora: Literary Transnationalism And Tranlingual Migrations. Cambria Press, Amherst, New York. Hardback 278pp. ISBN: 978-1-60497-860-5.
}

\author{
Rosalind Nicole McFarlane \\ University of Monash, Australia
}

Received: 09-08- 2013

doi:10.7575/aiac.ijclts.v.2n.1p.35
Accepted: 23-11- 2013

Published: 10-01- 2014

URL: http://dx.doi.org/10.7575/aiac.ijclts.v.2n.1p.35

\section{Review}

As a whole, this book aims to cross two major theoretical areas, translation theory and diasporic Asian writing. Situating herself at the crossroads of these areas, Karen An-Hwei Lee demonstrates how well these two areas combine, and how they can be fruitfully joined in order to close read texts. Each of the four chapters focuses on one or two prose works, though other works are used for comment. For close examination Lee chooses to engage with Virginia Woolf's To the Lighthouse (1927), the work of Sui Sin Far, Chuang Hua's Crossings (1968), Kazuo Ishiguro's A Pale View of Hills (1982) and Theresa Cha's Dictée (1982).

The highlight of each chapter is Lee's highly competent and engaging close textual analysis. Each point of the argument is supported with theory, examples from the text as well as situated within the criticism already written in the area. This allows Lee to make some complex and difficult arguments as she works through each piece of evidence systematically until, whether the reader ultimately agrees or not, they can certainly not fault her readings or their convincing nature. For example, the argument in the first chapter on Woolf's To the Lighthouse, a controversial choice for a book that aims to look at diasporic Asian literature, is presented when Lee proposes "the Orientalism in To the Lighthouse inflects a metaphysical discourse of cultural translation, I move beyond comparing the experience of being a woman artist and that of being Eurasian ... in order to indicate how the Orientalist vocabulary associated with Lily Briscoe points to a specific Eurasian discourse significant for translating multiple ways of knowing"(3). These kinds of careful arguments liberate Lee from what might be expected in such monographs and enable her to widen her range. It also allows her to examine canonical texts from new perspectives and offer different insights into these well discussed areas, insights that question the boundaries of existing interpretations.

This first chapter, examining the work of Woolf as well as that of Sui Sin Far, is united by Lee's focus on the idea of Eurasia or Eurasian and seeing. In the work of Far this representation of seeing, and the salvation it offers the family, is linked to a physical ailment. Lee argues that "[r]eaders see here the topos of emotional suffering, represented as a physical ailment, in Sui Sin Far's life, coupled with the trope of supernatural eyesight present in Eurasian discourse. It this case sharp sight is a positive attribute that not only redeems the seabird but also saves the life of her family." (21). The argument in regard to Lily Briscoe in To the Lighthouse is a lot more complex, and involves the relationship between representation, gender, art forms and the self. Lee's discussion of translation in terms of prosthesis as well as perception is involved and carefully constructed in a way that draws the reader through the layers of theory and textual analysis. This is certainly the densest of all the chapters, and at times the thread of the argument could be clearer. Certainly Lee often gives good overviews of chapters at the beginning (though for the first chapter this is not as clear as for the others) but leaves the conclusions very open. This is a strength in that, rather than being prescriptive and narrow in her ideas of translation or sight, Lee seeks to introduce different theoretical areas and viewpoints to make each individual argument. Instead of coming to an overly neat conclusion she embraces the perspectives each theory gives. However, at times a little more conclusion material would be preferable.

The second chapter, entitled "The Centre Shifts" examines Crossings by Chuang Hua and Lee draws on the way this novel uses "actual and figurative translation ... to demarcate the third, interstitial site where neither East nor West is absolutely referential or certain." (71) Lee develops this argument with great skill, using textual analysis to argue the "stylistic ambiguities of Crossings help Chuang Hua disidentify with Chinese and English culture by distancing herself from both while simultaneously using the sounds, memories, and experiences of both to weave her narrative, using translation as a metaphor for disidentification." (94). Lee takes this point of literary uncertainly, the uncertain space between the East and West, as a fertile ground to explore what a shifting third space may look like through the text. To do this Lee explores the use of silence in Crossings, which is privileged over utterance, and which she sees as "seeking fluency through the visual language of memory, dreams, and cinema." (83). Lee's discussion here is well handled, and generously supported with relevant theory and detailed, carefully elucidated close readings. All this leads to her central conclusion, and the idea that gives her chapter its title: the fact the title character of Crossings, Fourth Jane, is able to inhabit a shifting centre. For Lee this kind of identity does not locate loss or melancholia at its centre, but is one that is open to shifting and crossings. This is related back to translation by Lee, who sees such shifting as being like 
translation: "given that words cross from one language to another and that languages themselves are assimilations of foreign influences, perhaps the spirit of one language may migrate, in an ideal translation, into another" (129-30) and that such a shifting and crossing identity as depicted through Fourth Jane represents a form of being that is indeed in translation, one that makes up a third textual space.

Lee's third chapter is one of her strongest and has one of her most compelling arguments as she examines the work of Kazuo Ishiguro, and in particular the novel A Pale View of Hills. In this section Lee aims to explore Ishiguro's use of language, which she sees as fascinating as "the aesthetic polish of Ishiguro's novels is not simply skilful imitation of the modernists; rather, through the concept of a perfect simulation, it menaces the hegemonic concept of the original." (168). Lee sees this complication - what is translation if there is no original to reference - as forming a way for $A$ Pale View of Hills to "complicate not only the traditional concept of fidelity to an original and the hegemonic notion of on original but also the portrayal of a national and social referent." (140). Such an exciting idea is developed in the chapter as Lee investigates gender and music in relation to translation, as well as cinema. Most of Lee's chapters involve some kind of reference to visual material or the art of seeing, and it is definitely one of her strengths as an analyst. In this chapter, with her discussion of the Japanese shomin-geki cinema, Lee allows this talent to shine as she takes the reader through this genre, linking it to Ishiguro's novels in a way that allows her to draw detailed insights. She does not fall into the trap of letting this overpower her own analysis, though, and walks the line carefully between descriptive explanation, detailed analysis, and an acknowledgement of the limits of such an analysis. Rather than using such passages and close readings to make sweeping statements, Lee is careful to plot a course that draws insights without over-determining the usefulness of the theory. It is the combination of these two, the ability to use visual sources as a form of analysis, as well as not overstating the usefulness or impact of these, that gives Lee's analysis its strength and makes it all the more convincing.

Theresa Cha's Dictée is the subject of the final chapter of Anglophone Literatures in the Asian Diaspora and it is here that Lee focuses on the sacred as well as gender. While Lee sees Dictée as presenting a critique of "mystic texts by displacing, disjointing, erasing, unnaming, and reframing all these compositions" she identified the way "that Dictée's critique of dictation through unfaithful translation actually replaces the metaphysical logos with a desire for mystic speech and transparent mediation, for classical mystical language and mystical linguistic forms attempt to achieve transformations of consciousness." (189). This chapter includes discussions of martyrs, Korean history and feminism, all of which Lee interweaves with the reception, both historical and more recent, of Cha's work and its position within literary circles. Ultimately, while Lee does see Dictée as replacing what it seeks to critique, she nevertheless argues this is done in a way that does not simultaneously import the same power relations. Instead "Dictée ultimately achieves that pinnacle moment of private consciousness in which the reader and author, as Cha intended, are successfully bridged in dialogue ... Through the metonymic relationship of the page, the reader's association with Cha through artful constructions of proximity and privacy establishes a horizontal identification: not reader to author as God but, rather, private individual to private individual. Her words are the reader's words, her memories collectively theirs." (216). In this way Lee identifies the way in which Cha seeks another form of narrative, one that is not based on subjugation, and locates translation as a point of agency and empowerment.

One of the key strengths of this monograph is Lee's utilisation of Asian American criticism. However, this is not done in a way that colonises works that were written in other contexts. Asian American criticism can frequently offer insight into texts written in other contexts, but at times this can become overbearing and capable of ignoring the differences between the USA and countries such as Britain or Australia. However, Lee does not allow this to happen, and is careful to delineate what is useful from Asian American criticism when she applies it to texts outside its normal ambit. Each instance in which this happens is backed up with solid textual evidence to show why such an application is relevant, and how it might offer useful insight. In this way Lee draws attention to similarities and convergences, but does not ignore differences in so doing. As a form of criticism this is definitely to be commended, and shows a critic comfortable with diverse literatures and the criticism that might inform, or be used to comment up, such different texts.

Another strength of Lee's book is her use of translation and migration in ways that open out these categories, questioning assumptions in each, and using them in highly flexible ways. Examples of this include the use of translation in the chapter on Ishiguro, which allows Lee to question the idea that all translation must have an original, to the migration of martyrs from Korea to the USA through texts in the fourth chapter. Instead of insisting on strict definitions and controls, Lee allows her knowledge of these concepts to question and investigate the texts to see what they reveal, rather than what it is expected they contain. In this way the analysis is free to roam, to question, and to suggest with the flexibility of these concepts, rather than being bound by them.

Having described the wonderful flowing style of Anglophone Literatures, there was however a lack of strong conclusion material. The epigraph of the book is very short considering the detailed analysis that comes before, and while each chapter ends in a rather poetic way, there is also no real outright conclusion in any of them. At times the introduction sets out the argument to come well, but at times this is also diffuse. While this is not a great problem, and would probably not bother some readers, the fact Lee has such detailed and involved analysis, and such strong ideas, it seemed a shame it was not put forward directly in a conclusion as the scholarship is certainly strong enough to have warranted such claims.

What Lee's monograph aims to do is ambitious, and it certainly succeeds at this goal. The use of concepts such as translation and migration in a way that allows flexibility shows Lee's depth of knowledge in such areas, and her confidence in applying it to literary criticism. The close textual analysis is also carefully developed, convincing and allows Lee to draw highly insightful and fascinating conclusions. Finally, she situates her work in a wider field that show just how relevant literary scholarship can be to current scholarly debates, as well as to the contemporary world. 